
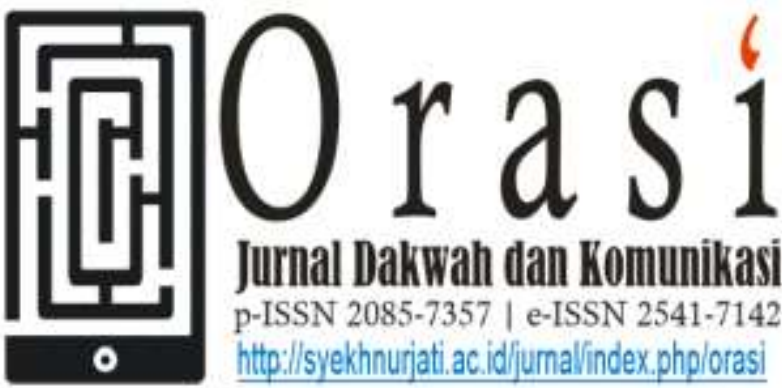

Volume 11 No. 2 Desember 2020

\title{
AKTUALISASI DAKWAH MELALUI MUSIK ROCK (Studi Tentang Pemanfaatan Musik Rock Oleh Afrizal Luthfi Lisdianta Sebagai Media Dakwah)
}

\section{ACTUALIZATION OF DA'WAH THROUGH ROCK MUSIC (A Study of Rock Music's Utilization by Afrizal Luthfi Lisdianta as A Medium of Da'wah)}

\author{
Muhammad Misbahul Huda1,a) \\ ${ }^{1}$ Magister Komunikasi dan Penyiaran Islam, UIN Sunan Kalijaga Yogyakarta \\ a)e-mail: hudamisbahul100297@gmail.com
}

\begin{abstract}
ABSTRAK
Degradasi/kemerosotan moral para pemuda di Indonesia kondisinya sangatlah memprihatinkan. Mulai dari para pemuda yang terlibat seks bebas, penggunaan obat-obat terlarang, kekerasan, problem psikologis, dan lain sebagainya. Berbagai faktor dituding sebagai penyebab kemerosotan moral tersebut, dapat dibilang bahwa faktor terbesar dari kemrosotan moral diakibatkan oleh gagap-nya para pemuda dalam mengarungi kerasnya globalisasi, arus informasi yang cepat, dan teknologi yang dari hari ke hari semakin canggih. Salah satu sample yang diambil adalah Afrizal Luthfi Lisdianta, pemuda yang bergelut di dunia musik rock dan menjalankan kewajiban sebagai seorang muslim, yakni berdakwah. Pertanyaan yang diajukan oleh peneliti adalah bagaimana aktualisasi dakwah Afrizal Luthfi Lisdianta: musik rock sebagai media dakwah. Metodologi penelitian ini menggunakan penelitian kualitatif dengan pendekatan studi kasus. Teknik pengumpulan data melalui metode observasi, wawancara, dan dokumentasi. Sedangkan teknik analisis datanya menggunakan model Miles Huberman, yang terdiri dari tiga tahap, yakni reduksi data, penyajian data, dan penarikan kesimpulan. Berdasarkan hasil penelitian dan analisis pembahasan, peneliti menyimpulkan aktualisasi dakwah Afrizal Luthfi Lisdianta: musik rock sebagai media dakwah terdapat tiga poin penting: (1) musik rock sebagai media dakwah bukan terletak pada syair/lagunya, akan tetapi pada lingkungan musik rock itu sendiri; (2) Afrizal dalam menyampaikan dakwahnya dengan cara tutur yang ringan (guyonan) bercanda; (3) beberapa pesan dakwah yang dismpaikan saat wawancara: mengajak salat, memperingatkan untuk tidak minum alkohol dan pergi ke diskotik/club, menjaga zina mata dan menjaga dari bersentuhan dengan
\end{abstract}


wanita yang tidak mahram, dan memberi solusi ketika ada masalah, disertai dengan pesan dakwah.

Kata Kunci: Aktualisasi, Dakwah, Musik Rock, Pemuda

\section{ABSTRACT}

The moral condition of the youth in Indonesia is very concerning, where many young people are involved in free sex, drug abuse, violence, psychological problems, and many others. Various factors contribute to the moral degradation, and the biggest one is the youth's stuttering in navigating the rigors of globalization, the fast flow of information, and the rapid development of technology. One good example is Afrizal Luthfi Lisdianta, a young man who is involved in the world of rock music but still carries out one of his obligations as a Muslim, namely da'wah. the research questions formulated how is the actualization of Afrizal Luthfi Lisdianta's da'wah: rock music as a medium of da'wah?. This research used a qualitative method with a case study approach. The data collection techniques applied were observations, interviews, and documentation. To analyse the data, the researcher implemented the MilesHuberman model, which consists of three stages, namely data reduction, data display, and conclusion drawing/verification. The results show that the actualization of Afrizal Luthfi Lisdianta's da'wah: rock music as a medium of da'wah has three important points: namely (1) rock music as a da'wah medium does not lie in the lyrics / songs, but in the rock music environment itself; (2) in delivering the message in da'wah, Afrizal made use of a light speech manner or jokes; (3) some of the da'wah messages conveyed during the interview were the reminder to pray, not to drink alcohol and go to discos/clubs, guard oneself from adultery and for men to avoid physical contacts with women who are not mahram, and provide solutions when there are problems.

Keywords: Actualization, Da'wah, Rock Music, Youth

\section{Pendahuluan}

Islam merupakan agama yang

berlandaskan Rahmatan lil Alamin.

Terminologi Rahmatal lil Alamin menurut KH.

Hasyim Muzadi adalah gagasan yang komprehensif, hal itu berkenaan dengan cara pemyampaian para $d a^{\prime} i$ yang membawakan Islam dengan penuh keramahan, kedamaian, dan kebijaksanaan, sehingga akan diterima dengan cara sukarela oleh masyarakat, dan yang paling penting tidak ada unsur perlawanan dan kekerasan (Muzadi 2006).
Rasyid (2016) mengungkapkan bahwa ada tiga metode yang yang berdasarkan konsep Rahmatal lil Alamin, yakni pendekatan dakwah, pendekatan hukum, dan pendekatan politik.

Sebelum menuju pada pendekatan hukum dan pendekatan politik, pendekatan dakwah merupakan pendekatan yang terbilang gerbang awal yang menentukan sukses tidaknya pemahaman Islam yang holistik bagi diri sendiri ataupun orang lain, sesuai dengan al-Qur'an dan Hadits. Dalam ayat al-Qur'an 
disebutkan bahwa "Dan hendaklah di antara kamu segolongan umat menyeru kepada kebajikan, menyuruh kepada yang makruf dan mencegah dari yang mungkar, merekalah orang-orang yang beruntung" (Q.S. Ali Imran: 104). Ditambah dengan Hadits Rasulullah, "Sampaikanlah dariku meskipun hanya satu ayat”. (HR. Tirmidzi). Dari kedua sumber utama tersebut, setidaknya memberi sebuah pemahaman bahwa adanya kewajiban dan keutamaan berdakwah bagi setiap muslim atau muslimah. Akan tetapi dalam praktiknya, dakwah tidak semudah yang dibayangkan. Perlu adanya aktualisasi diri, agar dakwah dapat mendekati keberhasilan. Sebab persoalan dan tantangan dakwah akan terus ada seiring dengan persoalan yang dihadapi oleh manusia.

Istilah aktualisasi diri dipopulerkan oleh salah satu tokoh psikologi yakni Abraham Maslow dalam bukunya yang berjudul Hierarchy Of Needs. Dalam buku tersebut disebutkan bahwa aktualisasi diri adalah sebuah kebutuhan yang meliputi memenuhi keberadaan diri (self fulfillment) dengan memaksimumkan penggunaan kemampuan dan potensi diri (http://id.m.wikipedia.org/wiki/Aktualisasi_dir i). Apabila aktualisasi diri diterapkan dalam kegiatan berdakwah, maka hal yang harus dilakukan adalah membenahi/memposisikan diri terhadap lingkungan dan memaksimalkan kemampuan dan potensi yang dimiliki dalam mengajak terhadap kebajikan.

Aktualisasi dakwah akan berjalan dengan optimal apabila dilakukan oleh pemuda. Pemuda merupakan fase di mana semangat juang, kegigihan, dan potensi yang dimiliki sangatlah masih kuat. Firman Allah: "Allah, Dialah yang menciptakan kamu dari keadaan lemah, kemudian Dia menjadikan (kamu) sesudah keadaan itu menjadi kuat, kemudian Dia menjadikan (kamu) sesudah kuat itu lemah (kembali) dan beruban. Dia menciptakan apa yang dikehendaki-Nya dan Dialah Yang Maha Mengetahui lagi Maha Kuasa" (QS. Ar-Ruum: 54). Ath-Thabari dalam (Hamad Hasan Raqith 2001) menjelaskan maksud ayat tersebut. Ayat tersebut mempunyai arti engkau dijadikan lemah lantaran usia tua, yakni masa sesudah kalian sangatlah kuat dan keras di masa remaja. Masa muda adalah puncak kegigihan manusia untuk mencari ilmu dan berpegang teguh pada agama. Selaras dengan ungkapan yang selalu diingat oleh Bangsa Indonesia dari Soekarno yang mengatakan, "Beri aku 10 pemuda, maka akan kuguncangkan dunia". Hal itu tidaklah berlebihan, karena para pemuda-lah yang disebut dengan generasi perubahan (agent of change).

Akan tetapi, sangat ironis ketika melihat data yang menunjukkan bahwa pemuda Indonesia mengalami kemerosotan moral. Misalnya pada penelitian yang dilakukan oleh (Ningrum 2015), data menunjukkan bahwa para pemuda terlibat dalam seks bebas, penggunaan obat-obatan terlarang, kekerasan, seks pra nikah, problem psikologis, dan lain sebagainya. Pusat Data Badan Koordinasi Kependudukan Keluarga Berencana (BKKBN) tahun 2007 dari 100 orang siswa, 5 diantaranya pernah melakukan seks pra nikah. Survey selanjutnya dilakukan 
oleh BKKBN di 33 provinsi di Indonesia tahun 2008 menyebutkan bahwa sekitar 63\% dari remaja terlibat hubungan seks pra nikah dan $21 \%$ remaja putri melakukan aborsi.

Dari data tersebut, dapat dipahami bahwa belum siapnya mental jasmani dan rohani dalam arus globalisasi dan gencarnya perkembangan teknologi, maupun informasi yang begitu cepat. Hal itu tentu akan sangat berdampak pada penurunan produktivitas dan kreativitas para pemuda. Dan yang paling terpenting adalah terkesan tidak mengindahkan batasan-batasan yang tertera dalam ajaran agama, khususnya Islam.

Apabila para pemuda mentaati betul batasan-batasan ajaran agama Islam, hal tersebut mungkin akan terhindarkan. Banyak sosok pemuda yang taat terhadap agama, setidaknya bisa menjadi teladan atau proyeksi. Salah satunya adalah Afrizal Luthfi Lisdianta. Afrizal Luthfi Lisdianta sebelum menjadi pebisnis untuk saat ini, dia adalah musisi band rock asal Yogyakarta. Musisi, apalagi musik rock bagi kebanyakan orang kesan pertama yang muncul adalah image negatif (dikelilingi wanita, alkohol, narkoba, dan lain sebagainya), dan hal itu memang wajar. Uniknya, sesuai dengan observasi, wawancara, dan dokumentasi oleh peneliti, image negatif yang disematkan oleh kebanyakan orang menjadi luntur ketika peneliti kenal dengan Afrizal. Dia mampu menjalankan hobinya, yaitu bermain musik "rock" dan mengajak temanteman band serta fansnya agar mematuhi aturan agama "berdakwah". Secara implisit Afrizal telah mempraktikkan dakwah melalui musik.
Beberapa penelitian yang relevan tentang dakwah melalui musik, misalnya (Lesmana 2015) grup nasyid Edcoustic menggunakan syair lagu sebagai media dakwah. (Rizqi 2010) grup Musik Kyai Kanjeng "Cak Nun" menggunakan syair lagu sebagai media dakwah. (Satria dan Mohamed 2017) hubungan dakwah dan seni terletak pada makna pesan yang dikandung. (Wahyudi 2010) dakwah sesuai dengan ilmu dan kemampuan, jika musisi baiknya menghasilkan karya yang bermanfaat. (Surya P.D 2018) dakwah melalui musik, lagu ciptaan Ahmad Dhani dengan judul "Satu" terkait makna yang dikandung. (Yanti 2016) nasyid sebagai media dakwah, sebab maraknya lagu religi. (Farihah 2013) pemanfaatan media pop sebagai jalan dakwah, misalnya tv, pers, majalah pop, musik, atau fiksi.

Dari sekian penelitian yang relevan, pembeda dari penelitian ini terletak pada bukan syair atau lagu yang dijadikan media dakwah, tetapi lingkungan musik rock-lah yang dijadikan media untuk aktualisasi dakwah oleh Afrizal. Salah satu kalimat yang disampaikan adalah "Saya harus tetap teguh pendirian sesuai ajaran agama, dan saya juga harus menjalankan kewajiban sebagai seorang muslim untuk tetap berdakwah, semampuku dan dimulai disekitarku”. Dari hal itu, peneliti tertarik untuk mengetahui bagaimana aktualisasi dakwah Afrizal Luthfi Lisdianta melalui musik rock sebagai media dakwah.

Maslow (1954) dalam bukunya Hierarchy of Needs menggunakan istilah aktualisasi diri (self actualization) sebagai kebutuhan dan pencapaian tertinggi seorang 
manusia. Dalam penelitian yang dilakukan oleh Kurniawan (2018) membagi tiga bagian dalam memahami istilah aktualisasi diri, yakni pengertian aktualisasi diri, aspek aktualisasi diri, dan faktor-faktor yang mempengaruhi aktualisasi diri. Pertama, pengertian aktualisasi diri. Maslow (dalam Arianto 2009) menjelaskan aktualisasi diri adalah proses menjadi diri sendiri dan mengembangkan sifat-sifat serta potensi psikologis yang unik. Menurut Maslow (dalam Omifaloji 2010) mengungkapkan proses-proses yang harus diperhatikan dalam aktualisasi diri ada lima, yakni siap untuk berubah, bertanggungjawab, memeriksa dan memiliki motif yang kuat, menggunakan pengalaman-pengalaman positif, dan siap terlibat dalam melakukan perkembangan. Dari definisi tersebut, dapat dipahami bahwa aktualisasi diri merupakan peningkatan kualitas atau potensi diri sesuai dengan keilmuan dan kemampuan yang dimiliki, baik materi maupun non materi.

Kedua, aspek aktualisasi diri. Aspek aktualisasi diri dibagi menjadi lima bagian, yakni kreativitas, moralitas, penerimaan diri, spontanitas, dan pemecahan masalah. Kreativitas identik dengan sifat yang energik, rasa eksplorasi hal-hal baru, optimis, dan lain sebagainya. Moralitas berkenaan dengan kemampuan seseorang yang berfokus pada nilai-nilai sikap atau perilaku yang mengarah pada hal baik. Penerimaan diri lebih pada mengenal dengan baik dirinya sendiri, menyelami diri hingga sampai puncaknya menerima "menghilangkan penilaian diri dan memperkuat penerimaan diri". Spontanitas lebih pada respon seseorang dalam menyesuaikan lingkungan yang ada. Sedangkan pemecahan masalah dalam aktualisasi diri merujuk pada menghargai keberadaan orang lain dan mencoba memahami berbagai masalah yang ada, akan lebih baik jika mampu memberikan solusi.

$$
\text { Ketiga, faktor-faktor yang }
$$
mempengaruhi aktualisasi diri. Faktor-faktor tersebut dibagi menjadi tiga bagian inti, yakni pemeliharaan, peningkatan diri, dan penerimaan positif dari diri sendiri. Pemeliharaan merupakan aspek awal di mana seorang manusia merawat dan menjaga apa yang sudah dia punya. Peningkatan diri merupakan aspek lanjutan dari pemeliharaan diri, setelah bisa memelihara diri, hal yang harus dilakukan adalah meningkatkan diri, baik dari segi potensi, kemampuan, pengetahuan, dan lainnya. Aspek terakhir adalah aspek penerimaan positif diri sendiri. Setelah memelihara dan meningkatkan diri, hal yang sangatlah penting adalah menerima dengan pikiran dan perasaan yang positif.

\subsection{Dakwah Islam}

Dakwah Islam sejatinya telah terpatri pada Firman Allah surat an-Nahl ayat 125 yakni perintah Allah kepada hamba-Nya untuk mengajak pada kebaikan dan mencegah pada kemungkaran. Menurut (Fakhruroji 2019) dalam merumuskan pemaknaan dakwah Islam, dibagi menjadi tiga sub, yakni pengertian dakwah Islam, dimensi dakwah Islam, dan dakwah Islam dan dinamikanya. Pertama, pengertian dakwah Islam. Menurut jenis, cakupan, dan karakter keilmuannya, aktivitas dakwah Islam dibagi menjadi empat kategori besar, yakni: (1) tabligh, upaya untuk 
penerangan dan penyebaran pesan "ajaran" Islam-konteksnya berkenaan dengan disiplin komunikasi; (2) irsyad, upaya bimbingan dan penyuluhan Islam-konteknya berkenaan dengan psikologi dan konseling; (3) tadbir, sebagai upaya pemberdayaan umat dalam menjalankan ajaran agama melalui lembaga dakwah-konteksnya lebih pada disiplin manajemen dan organisasi; serta (4) tathwir atau tamkin, sebagai upaya pemberdayaan kehidupan dan ekonomi keumatan masyarakatkonteksnya berkenaan dengan disiplin sosiologi, khususnya social engineering.

Dalam penelitian ini, istilah dakwah Islam tampaknya lebih mengarah pada tabligh. Karena tabligh memiliki banyak kesamaan dengan aktivitas komunikasi. Keduanya samasama menyampaikan pesan dan menggunakan media tertentu. Dan perbedaanya, terletak pada isi dan tujuan yang akan dicapai.

Kedua, dimensi dakwah Islam. Secara umum, aktivitas dakwah memiliki dua dimensi besar, yakni dimensi kerisalahan dan kerahmatan. Dalam kontes yag lebih luas, dimensi dakwah Islam tentang kerisalahan berkenaan dengan penyampaian teks agama sebagai ajaran yang ideal bagi manusia, sedangkan dimensi dakwah Islam dari segi kerahmatan adalah dimensi yang mengupayakan implementasi agama yang berkompromi dengan sosial-budaya dalam kehidupan seharu-hari.

Ketiga, dakwah Islam dan dinamikanya. Pada dasarnya, dakwah Islam adalah ajaran yang ditujukan sebagai rahmat dan keselamatan seraya membawa nilai-nilai positif bagi seluruh makhluk di dunia.
Perubahan ruang dan waktu, turut berkonsekuensi pada perubahan pola, pendekatan, metodologi, media, dan karakteristik dakwah. Maka dari itu, pemahaman dakwah Islam dan dinamikanya sama halnya pemaknaan dakwah yang bersifat situasional dan kontekstual sesuai situasi dan kondisi.

Sebelum memahami media (wasilah) dakwah, terlebih dahulu memahami bahwa media (wasilah) adalah bagian dari unsur atau rukun dakwah. Unsur atau rukun dakwah menurut (Sukayat 2015) membagi menjadi lima, yakni: (1) pelaku dakwah (da'i atau daiyah), pelaku dakwah adalah orang yang melaksanakan kegiatan dakwah, baik dari lisan, tulisan, atau perbuatan, yang dilakukan secara individu, kelompok, atau organisasi; (2) objek dakwah (mad'u), objek dakwah adalah orang yang diajak kepada Allah atau menuju al-Islam. Karena al-Islam bersifat universal, maka objek dakwah pun adalah manusia secara universal; (3) materi dakwah (maudhu' al da'wah), materi atau pesan dakwah adalah pesan-pesan yang berupa ajaran Islam atau segala sesuatu yang harsu disampaikan oleh subjek atau pelaku dakwah kepada objek dakwah yang bersumber dalam Kitabullah dan Sunah Rasulullah; (4) metode (uslub) dakwah, metode diartikan sebagai suatu cara untuk menyelesaikan suatu tujuan, rencana, sistem, atau tata pikir manusia; serta (5) media (wasilah) dakwah.

Secara bahasa, wasilah berasal dari bahasa Arab yang berarti: al-wuslah, al-Ittisal, yaitu segala hal yang dapat mengantarkan tercapainya kepada sesuatu yang dimaksud. 
Sedangkan secara istilah, wasilah adalah segala sesuatu yang dapat mendekatkan kepada sesuatu yang lainnya. Media (wasilah) dapat disamakan dengan alat, dalam hal ini alat yang digunakan sebagai perantara untuk melaksanakan kegiatan berdakwah diantaranya berupa: lisan, tulisan, visual, audio, dan keteladanan. Dengan demikian, media dakwah adalah alat yang bersifat objektif yang bisa menjadi saluran untuk menghubungkan ide dengan umat, atau diartikan sebagai elemen dari totalitas dakwah, sehingga keberadaan media sangat menentukan dalam perjalanan dakwah.

Menurut Said Mubarak (dalam Sukayat 2015), membagi dua bentuk wasilah dalah dakwah, yakni: (1) maknawiyah, yakni perantara yang mesti dilakukan oleh seorang $d a ' i$ dalam berdakwah, menyiapkan materi yang baik, waktu dan tempat yang tepat guna untuk kegiatan dakwah; dan (2) madiyah, yakni tatbiqiyah "orientasi tempat, seperti masjid, aula, atau pusat dakwah Islam", taqniyah "pengeras suara dan peralatan modern", dan asasiah "berupa ucapan atau wejangan serta gerakan menempuh perjalanan".

Ditambah dengan pendapat yang sampaikan oleh Asmuni Syukur (dalam Aziz, 2019) membagi media dakwah menjadi enam, yakni: (1) lembaga pendidikan formal; (2) lingkungan keluarga; (3) organisasi Islam; (4) Hari Besar Islam; (5) media massa; dan (6) seni budaya. Dilanjutkan dengan Barnawi Umar yang menyampaikan bahwa media dakwah berupa lisan, lukisan, tulisan, dan perbuatan.

\section{Metodologi Penelitian}

Peneltian ini menggunakan jenis penelitian kualitatif dengan pendekatan studi kasus. Pendekatan studi kasus berguna menghasilkan data-data yang sesuai dengan lapangan. Menurut Endraswara (2012: 78), studi kasus dapat dibagi menjadi dua golongan, yakni studi kasus berupa penyimpangan dari kewajaran dan yang kedua berupa studi kasus ke arah perkembangan yang positif. Subjek pada penelitian ini adalah Afizal Luthfi Lisdianta yang memposisikan dua subjek yakni sebagai musisi rock dan $d a{ }^{\prime} i$. Musik rock berfungsi sebagai media dakwah dalam perspektif lingkungan (circle) pergaulan Afrizal.

Penelitian ini menggunakan teknik pengumpulan data berupa observasi, wawancara, dan dokumentasi. Sumber datanya yakni primer dan sekunder. Teknik analisis data yang digunakan adalah teknik analisis data berupa reduksi model Miles dan Huberman, artinya dicapai dengan proses pemilihan, pemusatan, perhatian pada catatan tertulis di lapangan, penyajian data, dan verifikasi data.

\section{Hasil dan Pembahasan}

Sebagaimana yang telah dikemukakan, bahwa Afrizal Luthfi Lisdianta adalah sosok da'i muda sekaligus musisi band rock. Afrizal menjalankan dua subjek yang secara implisit bersebrangan. Satu sisi, Afrizal tetap menjalankan hobinya sebagai musisi rock, dan sisi yang lain Afrizal juga menjalankan salah satu kewajiban sebagai seorang muslim untuk mengajak kepada kebaikan dan mencegah 
terhadap kemungkaran (dakwah). Dalam hal musik, Afrizal memiliki band rock yang bernama Triple Seven dan penguatan keagamaan Afrizal ikut Majlis Rohis Fakultas KMIB (Keluarga Muslim Ilmu Budaya) Universitas Gadjah Mada Yogyakarta.

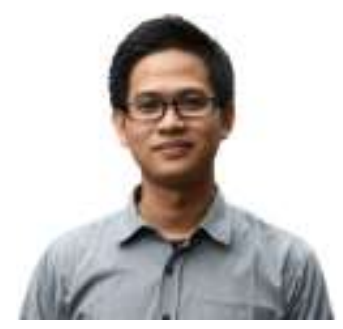

Gambar 1. Foto Afrizal Luthfi Lisdianta

Sudah barang tentu apabila Afrizal mengalami cukup kesulitan dalam menjalankan dua subjek tersebut. Paling tidak, ada tiga faktor yang menjadi kesulitannya: pertama, Afrizal adalah sosok anak muda yang belum mempunyai banyak pengalaman dalam hal menyampaikan pesan kebaikan (dakwah). Kedua, lingkungan musisi, apalagi musik rock adalah salah satu lingkungan yang tidak hanya mendapat image negatif oleh kebanyakan orang, akan tetapi memang begitu adanya, keidentikan lingkungan musisi rock adalah dikelilingi wanita, alkohol, narkoba, dan lainnya. Ketiga, Afrizal harus bisa memanfaatkan lingkungan musik rock-nya untuk menjadi media dakwah. Dan pada ranah inilah, akan terlihat aktualisasi dakwah yang akan dilakukan oleh Afrizal. Hal tersebut tentu agar tetap bisa menjalankan hobi "musisi band rock" dan kewajibannya "dakwah". Dan penggunaan musik sebagai media dakwah senada dengan apa yang disampaikan oleh Asmuni Syukur (dalam Aziz 2019), bahwa salah satu media dakwah yang dapat digunakan adalah seni-budaya, sedangkan musik merupakan salah satu cabang dari senibudaya. Setelah mengetahui pemanfaatan musik rock oleh Afrizal Luthfi Lisdianta untuk dijadikan sebagai media dakwah, pertanyaan selanjutnya adalah bagaimana aktualisasi dakwahnya.

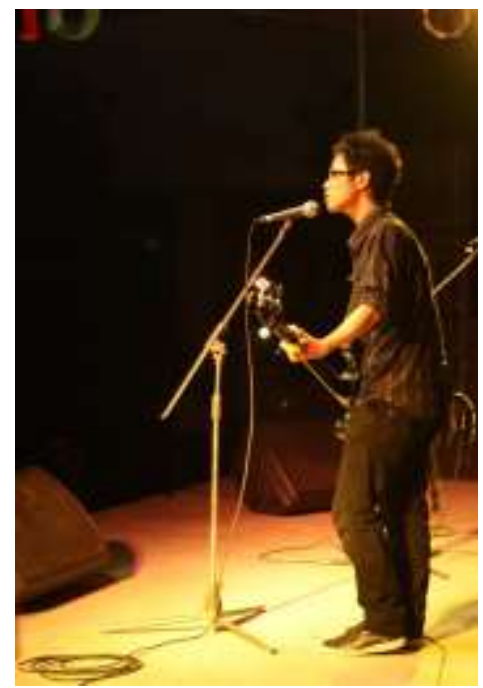

Gambar 2. Foto Afrizal Luthfi Lisdianta Saat Manggung

Dalam tataran aktualisasi, Maslow (1994) (dalam Alasso 2018) mengungkapkan, aktualisasi diri lebih bermotivasi pada pertumbuhan, bukan kekurangan. Orang yang akan mengaktualisasikan diri akan memecahkan persoalan yang dihadapi. Aktualisasi diri Afrizal Luthfi Lisdianta terwujud berdasarkan proses pemenuhan kebutuhan dan kewajiban sebagai muslim, sebab salah satu kewajiban dan kebutuhan seorang muslim adalah berdakwah di mana pun, dan kapan pun sesuai dengan kemampuan dan potensi yang dimiliki. Sebenarnya, Afrizal adalah seseorang yang hanya mengamalkan ibadah-ibadah seperti kebiasaan orang banyak, yakni salat dan mengaji. Kebiasaan tersebut 
Afrizal dapatkan dari didikan orang tuanya sejak kecil. Akan tetapi ketika Afrizal mengetahui dan lebih bersemangat dalam mendalami agama dan mentaati kewajiban berdakwah, di saat Afrizal ikut Majlis Rohis KMIB. Jika Afrizal sudah menganggap bahwa dakwah adalah kewajiban, maka seperti halnya makan. Dakwah sudah mulai menjadi kebutuhan. Artinya, proses yang akan dicapai oleh subjek (Afrizal) dikelompokkan Maslow ke dalam lima tingkat kebutuhan, yakni: (1) kebutuhan dasar fisiologis; (2) kebutuhan akan keselamatan; (3) kebutuhan akan cinta dan keselamatan; (4) kebutuhan akan harga diri; dan (5) kebutuhan akan aktualisasi diri. Jika digambarkan, maka akan tergambar sebagai berikut:

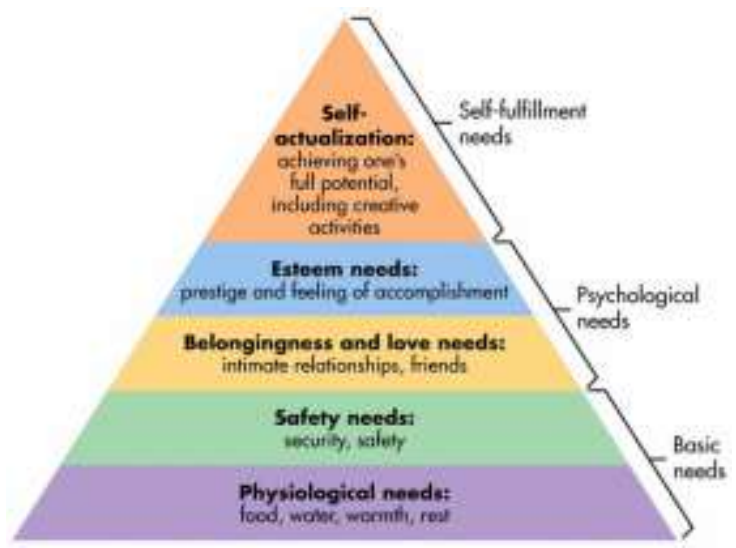

Gambar 3. Piramida Pemenuhan Kebutuhan Maslow

Sebelum menjabarkan pada proses pemenuhan kebutuhan "aktualisasi diri" oleh subjek. Dikira perlu untuk memahami hakikat dakwah Islam, agar tercapainya tujuan aktualisasi dakwah. Seperti yang sudah dijelaskan sebelumnya, dakwah Islam selalu bertendensi pada dua hal pokok, yakni kerisalahan (teks) dan kerahmatan (kontekstual). Bukan hanya berhenti pada hal itu, $d a{ }^{\prime} i$ “Afrizal" perlu benar-benar memahami bahwa Islam dan dakwah akan mengalami naik-turun "dinamika" sesuai ruang dan waktu, serta persoalan yang dihadapi oleh manusia secara universal, bukan hanya Islam dan bukan hanya orang yang masuk dalam kategori "baik" secara jasmani/rohani, melainkan semua manusia berhak untuk diikutsertakan dalam proses atau kegiatan berdakwah, baik berada pada subjek maupun objek. Hal itu diiringi dengan pemahaman unsur/rukun dakwah Islam, yakni subjek (da'i), objek (mad'u), materi (maudhu' al Da'wah), metode (uslub), dan media (wasilah).

Jika menarik pada teori pemenuhan kebutuhan Maslow, Afrizal sebagai subjek (da'i) sudah berada pada tingkat aktualisasi diri, dalam hal ini adalah berdakwah. Karena mulai dari tingkatan kebutuhan fisiologis, subjek sudah terpenuhi dari pemberian orang tua dan tambahan dari manggung, maka aspek makan, minum, dan kebutuhan fisik lainnya sudah terpenuhi. Sedangkan kebutuhan akan keselamatan, kebutuhan rasa cinta dan keselamatan, serta kebutuhan harga diri, sudah di back-up oleh agama yang dianutnya, yakni Islam dan bangsa yang menjadi tempat tinggalnya, yakni Bangsa Indonesia.

Dalam Islam misalnya, kebutuhankebutuhan tersebut sudah tersirat atau tersurat pada landasan Rahmatan lil Alamain (agama yang menebarkan cinta, kasih, aman, nyaman, dan keselamatan bagi seluruh alam). Sedangkan dalam sisi bangsa, Bangsa Indonesia merupakan salah satu bangsa yang 
berasaskan demokrasi dan menjunjung tinggi HAM.

Aktualisasi dakwah Afrizal Luthfi Lisdianta dengan memanfaatkan "lingkungan" musik rock sebagai media dakwah. Tentu dalam proses berdakwahnya mengalami tantangan yang berat bagi subjek, untungnya subjek memahami betul potensi, keilmuan, dan kemampuan dirinya sendiri. Maka dari itu, sasaran objek dakwah cukuplah pada diri sendiri, teman-teman se-band dan beberapa penggemarnya. Dan yang paling terpenting, materi (pesan) dakwahnya disampaikan secara ringan (guyonan-gasaki) dan istiqomah.

Beberapa kutipan wawancara dengan Afrizal yang menceritakan tentang dakwahnya, setidaknya ada empat poin penting yang berupa pesan dakwah, yakni: (1) selalu mengajak untuk salat, baik sebelum atau sesudah manggung (konteksnya yang menjadi objek adalah teman se-band), (2) selalu mencegah teman-teman se-band untuk tidak minum alkohol dan pergi ke diskotik/club setelah manggung; (3) selalu menjaga pandangan dan menjaga agar tidak bersentuhan dengan wanita yang bukan mahram (konteksnya dengan penggemar); dan (4) menjadi pendengar yang baik, di saat teman se-band mengalami sebuah masalah.

Pertama, selalu mengajak salat. Saat ditanya soal ibadah wajib, berupa salat.

"Kalo dalam hal salat, saya selalu mengajak temen-temen, dan tidak bosen-bosennya aku untuk mengajak. Padahal sampai saat itu pun, tidak pernah ada yang mau untuk saya ajak salat. Ada yang ber-alasan udah salat, tapi belum, ada yang bilang aku prei sek (libur dulu) pak ustad, dan lainlainnya".

Kedua, selalu memperingatkan untuk tidak minum alkohol dan pergi ke diskotik/club.

"Sering itu anak-anak, masih saja diminum padahal udah saya kasih tau loh kalo haram, sama satu lagi pergi ke club, ijeh wae koyo ngono (masih saja kayak gitu). Tapi kembali lagi, tugas saya cuma mengingatkan, hidayah urusan Allah".

Ketiga, selalu menjaga diri dari pandangan mata ke wanita dan bersentuhan "bersalaman" dengan wanita yang bukan mahram.

"Ya mau gimana lagi mas, namanya musisi pasti lah punya penggemar, banyak yang cewek lagi sampe pernah ada loh yang ngejar-ngejar. Saya ya sering mas, dikatain para penggemar saya yang katanya sombong lah, jual mahal, dan lain-lain. Tapi aku bodo amat, saya yakin dengan menjaga hal ini, akan berefek baik bagi saya dan semoga penggemar saya lambat-laun paham akan hal ini".

Keempat, menjadi pendengar yang baik saat teman-teman mendapat masalah dan sebisa mungkin memberikan solusi.

"Anak-anak kalo ada masalah ya cerita sama saya mas. Nah, pada saat ini saya juga masukin pesan-pesan dakwah dikit-dikit untuk menjadi solusinya".

Dari keempat pesan dakwah tersebut, menunjukkan bahwa kewajiban sebagai seorang muslim untuk berdakwah dan menjalankan hobi sebagai musik bisa berjalan dengan baik. Tantangan "lingkungan" musik rock yang dijalaninya, bahkan menjadi media dakwahnya Afrizal. 
Degradasi moral yang terjadi di Indonesia tentu menjadi pukulan telak bagi tatanan bangsa. Sebab, ada ungkapan yang mengatakan "Bangsa yang kuat, terdapat pemuda yang kuat pula". Tidak terlalu berlebihan ketika merujuk pada ungkapan tersebut, seyogyanya para pemuda-lah penerus generasi yang masih sangat kuat baik jasmani maupun rohani. Sosok Afrizal mungkin bisa dijadikan sebuah percontohan/teladan, di mana di masa mudanya dia memanfaatkan dengan melakukan hal-hal positif, seperti menghasilkan karya lewat musik dan berperan sebagai penyampai ajaran agama, walaupun tidak dari latar belakang anak kyai atau berprofesi sebagai $d a^{\prime} i$. Hal itu menunjukkan bahwa esensi dakwah ( $\left.d a^{\prime} i\right)$ adalah menyampaikan sesuai dengan kemampuan dan potensi, serta memanfaatkan media yang berada di sekitar secara optimal.

Hamad Hasan Raqith dalam bukunya yang berjudul Meraih Sukses Perjuangan Da'i, mengungkapkan enam alasan mendasar bahwa peran para pemuda sangatlah amat besar bagi berkembangnya ajaran agama Islam, yakni: (1) menyebarluaskan ilmu pengetahuan yang telah mereka peroleh, mengingat sabda Rasul: "Sebaik-baiknya kalian adalah orang yang belajar al-Qur'an dan mengajarkan". (HR. Bukhari); (2) menghindarkan diri dari perselisihan dan perdebatan yang hanya menimbulkan kebencian. Sabda Rasulullah: "Suatu kaum tidak tersesat setelah petunjukku, yang mereka berpegang teguh di atas-nya kecuali mereka melakukan perdebatan". (HR. Turmudzi); (3) berusaha melembutkan hati manusia dan menyatukan kehendak bersama.
Sabda Rasulullah: "Orang mukmin itu rmah dan diramahi, dan tiada kebaikan dalam diri orang yang tidak bersikap ramah dan diramahi ". (HR. Ahmad); (4) memberikan bantuan kepada orang lain dalam hal kebaikan. Firman Allah: "Dan mereka memberikan makanan yang disukainya kepada orang miskin, anak yatim dan orang yang ditawan. Sesungguhnya kami memberi makanan kepadamu hanyalah untuk mengharapkan keridahan Allah, kami tidak menghendaki balasan dari kamu dan tidak pula (ucapan) terimakasih". (QS. Al-Insaan: 8-9); (5) memanfaatkan segala kemampuan dan potensi yang dimiliki demi kemaslahatan dakwah, sebagaimana yang dilakukan oleh pemuda alArqam bin Abi al-Arqam, ketika menyumbangkan rumahnya untuk dijadikan pusat dakwah islam di masa awal; dan (6) Berupaya menjalankan misi dakwah secara perorangan. "Demi Allah, Allah menganugerahi petunjuk kepada seseorang lantaran dirimu adalah lebih baik daripada harta yang banyak"(HR. Asy-Syaikhani).

Setidaknya poin lima dan enam, sudah dijalankan oleh Afrizal Luthfi Lisdianta. Dengan memanfaatkan segala kemampuan dan potensi diri dan berdakwah secara perorangan. Inilah titik yang disebut dengan pentingnya peranan para pemuda dalam kegiatan dakwah, bahkan pada kegiatan apapun pemuda sangat berguna "dalam hal positif".

\section{Simpulan}

Berdasarkan temuan hasil penelitian, peneliti dapat menyimpulkan bahwa: 
1. Aktualisasi dakwah Afrizal Luthfi Lisdianta: musik rock sebagai media dakwah ada tiga poin penting, yakni: (a) seni musik yang menjadi media dakwah Afrizal bukan terletak pada syair/lagu yang diciptakan. Melainkan pemanfaatan lingkungan musik rock tersebut sebagai media dakwahnya; (b) Afrizal dalam menyampaikan dakwahnya dengan cara tutur yang terkesan bercanda (ringan), atau dalam bahasa Jawa disebut dengan guyonan-gasaki. Sehingga lebih mudah diterima oleh teman-teman dan penggemarnya; (c) beberapa pesan dakwah yang disampaikan pada saat wawancara meliputi: mengajak untuk salat, memperingatkan untuk tidak minum alkohol dan pergi ke diskotik/club, selalu menjaga diri dari zina mata dan bersentuhan (berjabat-tangan) dengan wanita yang bukan mahram, dan memberikan solusi dari setiap masalah yang ada, dengan dibumbui pesan-pesan ajaran agama.

2. Peranan pemuda dalam dakwah Islam dibagi menjadi enam: (a) menyebarluaskan ilmu pengetahuan yang diperoleh; (b) menghindarkan diri dari perselisihan dan perdebatan yang berujung pada kebencian; (c) berusaha melembutkan hati manusia dan menyatukan kehendak bersama; (d) memberikan bantuan kepada orang lain dalam hal kebaikan; (e) memanfaatkan segala kemampuan dan potensi yang dimiliki demi kemaslahatan umat; dan (f) berupaya menjalankan dakwah perorangan.

\section{Daftar Pustaka}

Alasso, Elisha Orcarus. 2018. "Aktualisasi Diri Ki Seno Nugroho: Tinjauan Pemenuhan Kebutuhan dalam Teori Motivasi Abraham H. Maslow". Journal of Pupperty (Wayang Nusantara) 2 (3). (10.24821/wayang.v2i2.3051).

Aziz, Moh. Ali. 2019. Ilmu Dakwah. Jakarta: Kencana.

Endraswara, Suwardi. 2012. Filsafat Sastra: Hakikat, Metodologi dan Teori. Yogyakarta: Layar Kata.

Fakhruroji, Moch. 2019. Dakwah di Era Media Baru: Teori dan Aktivisme Dakwah di Internet. Bandung: Simbiosa Rekatama Media.

Irzum, Farihah. 2013. "Media Dakwah Pop". Jurnal AT-Tabsyir 1 (https://journal.iainkudus.ac.id).

Kurniawan, Imam. 2018. "Gambaran Aktualisasi Diri Peyandang Disabilitas Di Yogyakarta". Skripsi: Universitas Mercu Buana Yogyakarta. (http://eprints.mercubuanayogya.ac.id/2401).

Lesmana, Luki Agung. 2015. "Implementasi Dakwah islam Melalui Seni Musik Islami (Studi Deskriptif Pada Grup Nasyid EdCoustic)". Jurnal TARBAWY 2 (1). (https://ejournal.upi.edu/index.php/tarba wy/article/view/3376).

Muzadi, Abdul Muchit. 2006. Mengenal Nahdlatul Ulama. Surabaya: Khalista.

Ningrum, Diah. 2015. "Kemrosotan Moral Di Kalangan Remaja: Sebuah Penelitian Mengenai Parenting Styles dan Pengajaran Adab". Jurnal UNISIA, 37 (82).

(https://journal.uii.ac.id/unisia/article/vie w/10491).

Raqith, Hamad Hasan. 2001. Meraih sukses Perjuangan Da'i. Yogyakarta: Mitra Pustaka.

Rasyid, Maknun Muhammad. 2016. "Islam Rahmatal Lil Alamin Perspektif KH. Hasyim Muzadi”. Jurnal Episteme: 
Jurnal Pengembangan Ilmu Keislaman 11 (https://doi.org/10.21274/epis.2016.11.1. 93-116).

Rizqi, Robbi Isthafani. 2010. "Dakwah Melalui Seni Pertunjukan Oleh Kiai Kanjeng (Studi Pementasan pada tanggal 17 Februari 2010 di Bantul Yogyakarta)". Skripsi: Universitas Islam Negeri Sunan Kalijaga Yogyakarta. (http://digilib.uin-suka.ac.id/5600/).

Satria, Eri dan Roslan Mohamed. 2017. "Analisis Terhadap Peranan Nasyid Dalam Dakwah". Jurnal Ilmiah Islam Futura. $16 \quad$ (2). (http://dx.doi.org/10.22373/jiif.v16i2.132 9).

Sukayat, Tata. 2015. Ilmu Dakwah Perspektif Mabadi' 'Asyarah. Bandung: Simbiosa Rekatama Media.

Surya P.D, Dimas. 2018. "Dakwah Melalui Musik: Analisis Pesan Isi Pesan Dakwah Lagu 'Satu' Dalam Album Laskar Cinta Karya Ahmad Dhani”. Skripsi: UIN Sunan Ampel Surabaya. (http:digilib.uinsby.ac.id/22951/).

Wahyudi, Ade. 2010. "Dakwah Melalui Musik (Kiprah Opick dalam Berdakwah Melalui Musik)". Skripsi: UIN Syarif Hidayatullah Jakarta. (http://repository.uinjkt.ac.id).

Yanti, Fitri. 2016. "Komunikasi Dakwah Dalam Kesenian Nasyid". Jurnal alMishbah. 12 (2). (https://almishbahjurnal.com/index.php/a 1-mishbah/article/view/71). 
186 | Muhammad Misbahul Huda

(Halaman ini sengaja dikosongkan untuk kebutuhan tata letak)

Orasi: Jurnal Dakwah dan Komunikasi | Volume 11, No. 2, Desember 2020 